\title{
Inherited forms of renal hypomagnesemia: an update
}

\author{
Nine V. A. M. Knoers
}

Received: 11 June 2008 / Revised: 22 July 2008 / Accepted: 23 July 2008 / Published online: 26 September 2008

(C) The Author(s) 2008. This article is published with open access at Springerlink.com

\begin{abstract}
The kidney plays an important role in ion homeostasis in the human body. Several hereditary disorders characterized by perturbations in renal magnesium reabsorption leading to hypomagnesemia have been described over the past 50 years, with the most important of these being Gitelman syndrome, familial hypomagnesemia with hypercalciuria and nephrocalcinosis, familial hypomagnesemia with secondary hypocalcemia, autosomal dominant hypomagnesemia with hypocalciuria, and autosomal recessive hypomagnesemia. Only recently, following positional cloning strategies in affected families, have mutations in renal ion channels and transporters been identified in these diseases. In this short review, I give an update on these hypomagnesemic disorders. Elucidation of the genetic etiology and, for most of these disorders, also the underlying pathophysiology of the disease, has greatly increased our understanding of the normal physiology of renal magnesium handling. This is yet another example of the importance of studying rare disorders in order to unravel physiological and pathophysiological processes in the human body.
\end{abstract}

Keywords Claudins · EGF - Gitelman syndrome · Hypomagnesemia $\cdot \mathrm{Mg}^{2+} \cdot \mathrm{Na} / \mathrm{K}$-ATPase $\gamma$-subunit $\cdot \mathrm{NCC}$. TRPM6

N. V. A. M. Knoers $(\bowtie)$

Department of Human Genetics 849,

Radboud University Nijmegen Medical Centre,

P.O. Box 9101, 6500 HB Nijmegen, The Netherlands

e-mail: n.knoers@antrg.umcn.nl
Physiology and pathophysiology of magnesium handling

Magnesium $\left(\mathrm{Mg}^{2+}\right)$ is the second-most abundant intracellular cation and plays an essential role in a wide variety of biological activities. Normal $\mathrm{Mg}^{2+}$ concentration (0.75$1.4 \mathrm{mmol} / \mathrm{L}$ ) in the human body is balanced by changes in urinary $\mathrm{Mg}^{2+}$ excretion in response to altered uptake by the intestine. The main site of absorption is the small bowel where approximately one third of dietary $\mathrm{Mg}^{2+}$ is absorbed. Some additional absorption takes place in the large bowel. Absorption in the small bowel occurs via paracellular simple diffusion at high intraluminal concentrations and, at low concentrations, by active transcellular uptake via the recently identified $\mathrm{Mg}^{2+}$ channel TRPM6 (transient receptor potential channel melastatin 6), which is expressed along the brush border membrane of the small intestine [1]. Regulation and fine-tuning of serum the $\mathrm{Mg}^{2+}$ concentration occurs primarily in the kidney. Approximately $2500 \mathrm{mg}$ of $\mathrm{Mg}^{2+}$ is filtered per day, of which $96 \%$ is reabsorbed along the nephron and only a small portion (5$15 \%)$ in the proximal tubule. The major site of passive reabsorption is the thick ascending limb (TAL) of Henle's loop, where $50-72 \%$ of the filtered $\mathrm{Mg}^{2+}$ is reabsorbed through the paracellular pathway. Active reabsorption of $\mathrm{Mg}^{2+}$ takes place in the distal convoluted tubule (DCT) and accounts for $10 \%$ of the total filtered load. Because the DCT is the last site of $\mathrm{Mg}^{2+}$ reabsorption, the final urinary secretion of $\mathrm{Mg}^{2+}$ is determined here. The epithelial $\mathrm{Mg}^{2+}$ channel, TRPM6, is essential for the apical influx of $\mathrm{Mg}^{2+}$ in DCT cells. The mechanisms of cytosolic $\mathrm{Mg}^{2+}$ diffusion and basolateral transport of $\mathrm{Mg}^{2+}$ are not yet clear.

Hypomagnesemia is a common finding in hospitalized patients and often an acquired disorder resulting from deficient oral intake or accelerated urinary or intestinal loss. Acquired renal magnesium wasting is commonly caused by 
drug therapy (i.e. diuretics, aminoglycosides, immunosuppressive agents), alcohol, and osmotic diuresis (i.e. diabetes mellitus). Hypomagnesemia has also recently been described as a frequent, and sometimes severe, side effect of cetuximab therapy, a monoclonal antibody against the epidermal growth factor receptor (EGFR) used in the treatment of colorectal cancer [2].

The most important genetic causes of hypomagnesemia are summarized in Table 1 and will be discussed in more detail below

\section{Hypomagnesemic disorders caused by defects localized in the TAL}

Familial hypomagnesemia with hypercalciuria and nephrocalcinosis

Familial hypomagnesemia with hypercalciuria and nephrocalcinosis (FHHNC; OMIM 248250) is an autosomal recessive renal disorder characterized by excessive renal $\mathrm{Mg}^{2+}$ wasting, resulting in persistent hypomagnesemia, renal $\mathrm{Ca}^{2+}$ wasting, bilateral nephrocalcinosis, and progressive renal failure [3-6]. Symptoms usually begin in the first few months of life. Affected individuals present with recurrent urinary tract infections, polyuria/polydipsia, nephrolithiasis, and/or failure to thrive. Additional symptoms at manifestation include abdominal pain, convulsions, muscular tetany, incomplete distal renal tubular acidosis, and hypocitraturia [3, 4, 7, 8]. Some authors have reported elevated serum parathyroid hormone levels early in the course of the disease [3, 7]. Hyperuricemia is observed in the majority of patients $[3,9,10]$. Ocular abnormalities (severe myopia, nystagmus and chorioretinitis) and hearing impairment have been reported as inconsistent extrarenal symptoms in FHHNC [6].

Renal function declines progressively in approximately $30 \%$ of FHHNC patients, and many of these patients reach end-stage renal disease in their teenage or young adult years [11]. Most patients with FHHNC are initially treated with oral citrate, thiazides, and high-dose enteral magnesium, which may normalize some biochemical abnormalities but do not always result in delayed progression of renal dysfunction $[3,6,11,12]$.

Table 1 Inherited disorders of magnesium transport

\begin{tabular}{|c|c|c|c|}
\hline Disease $/ \mathrm{OMIM}^{\mathrm{a}}$ & $\begin{array}{l}\text { Gene/ } \\
\text { inheritance }^{\mathrm{b}}\end{array}$ & Protein $^{\mathrm{b}}$ & Key clinical/biochemical symptoms \\
\hline Gitelman syndrome/ 263800 & $S L C 12 A 3 / \mathrm{AR}$ & $\mathrm{NCC}$ & $\begin{array}{l}\text { Muscle weakness/tetany } \\
\text { Fatigue } \\
\text { Chondrocalcinosis } \\
\text { Hypomagnesemia } \\
\text { Hypocalciuria }\end{array}$ \\
\hline $\begin{array}{l}\text { Familial hypo-magnesemia with hypercalciuria } \\
\text { and nephrocalcinosis/ } 248250 / 248190\end{array}$ & $\begin{array}{l}C L D N 16 / \mathrm{AR} \\
C L D N 19 / \mathrm{AR}\end{array}$ & $\begin{array}{l}\text { Claudin-16 } \\
\text { Claudin-19 }\end{array}$ & $\begin{array}{l}\text { Polyuria } \\
\text { Renal stones/ } \\
\text { nephrocalcinosis } \\
\text { Ocular abnormalities } \\
\text { Severe hypomagnesemia } \\
\text { Hypercalciuria }\end{array}$ \\
\hline Autosomal dominant isolated renal Mg loss/ 154020 & $F X Y D 2 / \mathrm{AD}$ & $\begin{array}{l}\gamma \text {-Subunit sodium potassium } \\
\text { ATPase }\end{array}$ & $\begin{array}{l}\text { Seizures } \\
\text { Chondrocalcinosis } \\
\text { Hypomagnesemia } \\
\text { Hypocalciuria }\end{array}$ \\
\hline $\begin{array}{l}\text { Familial hypomagnesemia with secondary } \\
\text { hypocalcemia/ } 602014\end{array}$ & TRPM6/AR & $\begin{array}{l}\text { Epithelial magnesium } \\
\text { channel TRPM6 }\end{array}$ & $\begin{array}{l}\text { Tetany/seizures } \\
\text { Hypomagnesemia } \\
\text { Hypocalcemia }\end{array}$ \\
\hline Autosomal recessive isolated renal $\mathrm{Mg}$ loss & $E G F / \mathrm{AR}$ & Epidermal growth factor & $\begin{array}{l}\text { Tetany/seizures } \\
\text { Hypomagnesemia } \\
\text { Normocalciuria }\end{array}$ \\
\hline
\end{tabular}

${ }^{a}$ Online Mendelian Inheritance in Man numbers. Available at: http://www.ncbi.nlm.gov/omim/OMIM

${ }^{\mathrm{b}}$ AR, Autosomal recessive; AD, autosomal dominant; SLC, solute carrier; EGF, epidermal growth factor; TRPM6, transient receptor potential channel melastatin 6, CLDN, claudin; $\mathrm{NCC}, \mathrm{NaCl}$ cotransporter 
Thus, the overall prognosis of FHHNC is poor, and a definite cure can only be achieved by renal transplantation.

In most cases, FHHNC is caused by loss-of-function mutations in the CLDN16 gene, which encodes claudin-16 (formerly paracellin-1), an important tight junction protein of the claudin family, that is expressed in the TAL of Henle's loop and in the DCT [11-14]. The claudin family comprises a set of structurally related proteins involved in the formation of tight junction proteins in various tissues [15]. The mutations in CLDN16 identified in FHHNC patients consist of premature termination codons, splice-site mutations, and missense mutations, all of which are located within the extracellular loops or the transmembrane domains of the claudin-16 protein [11-14]. In Germany and Eastern European countries a founder mutation $(\mathrm{L} 151 \mathrm{~F})$ in the first extracellular loop of claudin-16 has been identified that is present in approximately $50 \%$ of mutant alleles [11]. This finding greatly facilitates molecular diagnosis in patients originating from these countries. Konrad et al. recently reported that patients who have FHHNC and are affected by two loss-of-function mutations in the CLDN16 gene have an early onset of chronic renal failure, whereas patients with at least one mutation with residual function are protected from the rapid loss of renal function [14].

Interestingly, a novel homozygous CLDN16 mutation (T233R) has been identified in two families with selflimiting childhood hypercalciuria. The hypercalciuria decreased with age and was not associated with declined renal function. The T233R mutation is the first mutation to be identified in the cytosolic tail of claudin-16 and results in inactivation of the PDZ-domain-binding motif. This inactivation abolishes the association with the tight-junction scaffolding protein $\mathrm{ZO}-1$, with subsequent accumulation of the mutant claudin-16 protein in lysosomes and no localization to the tight junction [16]. These findings indicate that the clinical phenotype of mutations in claudin-16 is likely to be determined by the location of the mutation within the gene; mutations affecting amino acids at the extracellular and transmembrane segments cause classical FHHNC, while mutations affecting specific amino acids in the cytosolic domain cause a spontaneously resolving hypercalciuria.

In a subset of families with FHHNC and severe ocular involvement (OMIM 248190), the disease was shown to be caused by mutations in the CLDN19 gene, which encodes claudin-19, another important tight junction protein expressed in renal tubules and the eye [17].

The precise function of claudin-16 and -19 and their role in FHHNC remain to be elucidated. It was initially assumed that claudin-16 has high selective paracellular permeability for magnesium and calcium. However, based on the results of electrophysiological studies in LLC-PK1 epithelial cells expressing human claudin-16, Hou and coworkers reported that claudin-16 has only a low permeability for magnesium, but a much higher one for sodium. These researchers proposed that claudin-16 may form a paracellular shunt for sodium from the interstitium to lumen, thereby contributing to the lumen positive potential [18]. This proposal was further substantiated in a mouse model with highly reduced claudin-16 expression, which displayed magnesuria and calciuria, loss of bone mass, and nephrocalcinosis. Detailed analysis of the TAL function in this model revealed decreased paracellular sodium permeability and strongly reduced lumen positive potential [19]. Taken together, these findings strongly suggest that claudin-16 is part of the tight junction complex that selectively mediates sodium backleak into the TAL lumen, thereby generating a higher lumen positive potential, which is critical for paracellular reabsorption of sodium and magnesium (Fig. 1).

\section{Hypomagnesemic disorders caused by defects localized in the DCT}

\section{Gitelman syndrome}

Gitelman syndrome (GS) (OMIM 263800) is an autosomal recessive salt-losing renal tubulopathy that is characterized

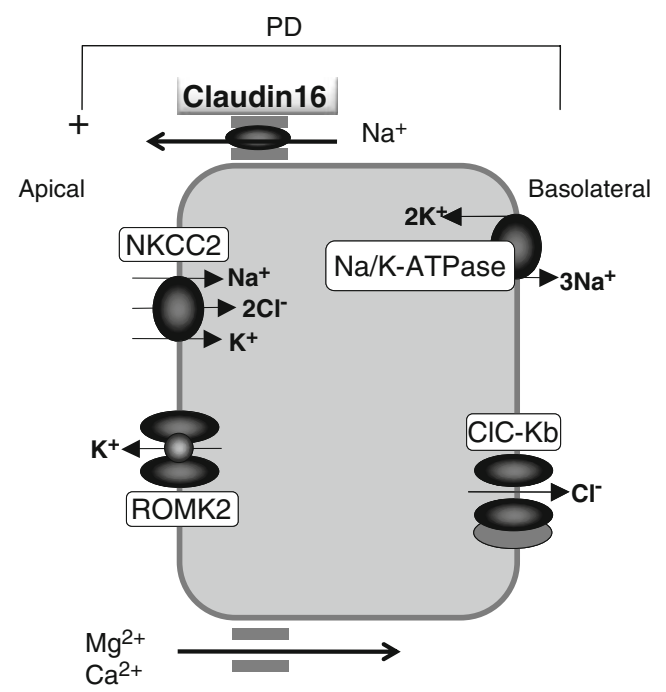

Fig. 1 Speculative model of magnesium transport in the thick ascending limb of Henle's loop. Sodium chloride enters the cell via the apical $\mathrm{Na}^{+}, \mathrm{K}^{+}, 2 \mathrm{Cl}{ }^{-}$cotransporter $(N K C C 2)$. Potassium is recycled into the lumen via the luminal ATP-regulated inwardly rectifying potassium channel (ROMK2). Chloride leaves the cell through the basolateral $\mathrm{Cl}^{-}$channel $(C l C-K b)$ and sodium via the basolateral $\mathrm{Na}^{+} / \mathrm{K}^{+}$-ATPase complex. A lumen-positive potential $(P D)$ is established by the actions of NKCC2 and ROMK2. Sodium partially leaks back into the lumen via claudin-16, increasing this lumen positive potential, thereby driving magnesium and calcium reabsorption via the paracellular pathway 
by hypomagnesemia, hypocalciuria, and secondary aldosteronism which is responsible for hypokalemia and metabolic alkalosis [20]. The prevalence is estimated at approximately 25 per million and, accordingly, the prevalence of heterozygotes is approximately $1 \%$ in Caucasian populations, making it one of the most frequent inherited renal tubular disorders [21].

Patients with GS usually present above the age of 6 years, and in many cases the diagnosis is only made at adult age. Most patients suffer from tetany, especially during periods of fever or when extra magnesium is lost due to vomiting or diarrhea. Paraesthesias, especially in the face, frequently occur. Some patients experience fatigue so severe that it interferes with daily activities, while others never complain of tiredness. The severity of fatigue in GS is not completely related to the degree of hypokalemia. In contrast to Bartter syndrome, which is a genetically distinct and clinically more severe tubular transport disorder that shares the hypokalemic metabolic alkalosis with GS, polyuria is usually absent or only mild in GS. In general, growth is normal in GS patients; however, it can be delayed in patients with severe hypokalemia and severe hypomagnesemia [22]. Many adult GS patients suffer from chondrocalcinosis, which is assumed to result from chronic hypomagnesemia [23]. This condition causes swelling, local heat, and tenderness over the affected joints. Cruz and colleagues have challenged the generally accepted idea that GS is a mild disorder [24]. They evaluated the symptoms and quality of life (QOL) in 50 adult patients with molecularly proven GS and compared this cohort of patients with 25 age- and sex-matched controls. They found that GS patients had significantly more complaints than controls, mainly salt craving, musculoskeletal symptoms, such as cramps, muscle weakness, and aches, and constitutional symptoms, such as fatigue, generalized weakness and dizziness, and nocturia and polydipsia. In addition, measures of QOL were significantly lower in GS patients than in controls.

Potassium and magnesium depletion prolong the duration of the action potential of cardiomyocytes and consequently increase the risk of developing ventricular arrhythmia. Electrocardiograms of patients with GS have shown that in about $50 \%$ of cases the QT interval is indeed slightly to moderately prolonged but, fortunately, is not associated with clinically relevant cardiac arrhythmias in the far majority of cases [25]. Sudden cardiac arrest has been reported in a few patients with GS $[22,26]$, indicating the advisability of systematic cardiac screening for such patients in order to identify other possible triggering mechanisms or underlying conditions. Blood pressure in GS patients is lower than in the general population, indicating that even the modest salt wasting of this disease reduces blood pressure. The results from a recent study in
35 GS carriers (with one mutant gene allele) suggest that GS carriers also have lower blood pressure and may be protected from hypertension [27]. Another study in a large cohort also demonstrated reduced blood pressure in subjects having one mutant gene allele [28]. These results are distinct from those reported in a previous study in an Amish kindred, in which no reduction of blood pressure was demonstrated in adult patients, despite increased $\mathrm{Na}^{+}$ excretion [29]. Thus, further studies are required to investigate whether the incidence of cardio-vascular events differs between GS patients or carriers compared to the control population.

The diagnosis of GS is based on clinical symptoms and biochemical abnormalities. The most typical biochemical abnormalities in GS patients are hypokalemia, hypomagnesemia, and hypocalciuria. Compared to Bartter syndrome, serum potassium concentration is comparably low (2.7 \pm $0.4 \mathrm{mmol} / \mathrm{L}$ ). Serum magnesium concentration is low (less than $0.65 \mathrm{mmol} / \mathrm{L}$ ). In a small number of GS patients it is possible to easily maintain the magnesium concentration in the normal range early on, which may lead to a false diagnosis of Bartter syndrome; in these patients, the magnesium concentration only drops below normal with time (personal observation). Hypomagnesemia and hypocalciuria have always been considered obligate features for GS. This assumption has been disputed by Lin et al. [30] who reported two families with molecularly proven GS in which male patients had severe hypokalemia and were symptomatic with episodes of paralysis, impaired urinary concentration ability, but with normal serum magnesium and urinary calcium excretion. Remarkably, female GS patients within these families, carrying the same causative mutations as the male patients, were asymptomatic, had less severe hypokalemia, and maintained intact urine concentration ability, but they did have hypomagnesemia and hypocalciuria [30]. Although this was a small study, the authors concluded that gender may affect phenotypic expression in GS and that hypomagnesemia and hypocalciuria may not be invariant features of the disorder.

Prostaglandin excretion is normal, and plasma renin activity and plasma aldosterone concentration are only slightly elevated compared to Bartter syndrome. Renal functional studies have demonstrated a normal or slightly decreased urinary concentrating mechanism, but clearly reduced distal fractional chloride reabsorption during hypotonic saline infusion. Patients with GS have a blunted natriuretic response to hydrochlorothiazide administration, but a prompt natriuresis after administration of furosemide, indicating that the defect in GS is located at the level of the distal tubule.

Most patients with GS remain untreated. However, in view of the assumption that chondrocalcinosis is due to magnesium deficiency, there is a clear argument for lifelong 
supplementation of magnesium. Normalization of serum magnesium is difficult to achieve since high doses of magnesium cause diarrhea. The bioavailability of magnesium preparations is different. Magnesium oxide and magnesium sulfate have a significantly lower bioavailability than magnesium chloride, magnesium lactate, and magnesium aspartate [31]. Hypokalemia can be treated by drugs that antagonize the activity of aldosterone or block the epithelial sodium channel $(\mathrm{ENaC})$ in the collecting duct. We prefer the combination of amiloride with $\mathrm{KCl}$.

In general, the long-term prognosis of GS is good. However, the severity of fatigue may seriously hamper some patients in their daily activities. Progression to renal insufficiency is extremely rare in GS. As yet, only one patient who developed chronic renal insufficiency and subsequent progression to end-stage renal disease has been reported [32].

In the great majority of cases, GS is caused by mutations in the solute carrier family 12 , member 3, SLC12A3 gene, which encodes the renal thiazide-sensitive sodium chloride cotransporter $(\mathrm{NCC})$ that is specifically expressed in the apical membrane of cells in the first part of the DCT (reviewed in [33]). The NCC is a 1021-amino acid polypeptide, and the two-dimensional structure is predicted to contain 12 transmembrane domains and long intracellular amino- and carboxytermini [34]. At present, more than 140 different putative loss-of-function mutations in the SLC12A3 gene have been identified in GS patients (collected in Human Gene Mutation Database HGMD, http://www.hgmd.cf.ac.uk/). Most are missense mutations substituting conserved amino acid residues within putative functional domains of NCC, whereas nonsense, frameshift-, and splice-site mutations and gene rearrangements are less frequent.

Functional expression studies and immunocytochemistry analyses of Xenopus leavis oocytes revealed that most disease-causing NCC mutants belong to the so-called type 2 mutations. These type 2 mutations are missense mutations or insertions/deletions of one or more nucleotide triplets, resulting in fully translated proteins. Due to the mutation, however, these mutant receptors are misfolded and retained in the endoplasmic reticulum (ER), as the ER is the organelle that has the cellular quality control over proper folding and maturation of synthesized proteins. Misfolded proteins are subsequently targeted for proteasomal degradation. De Jong and coworkers have shown that NCC misfolding resulting in defective trafficking to the plasma membrane in GS is not uniformly complete [35]. Some mutant NCC proteins are only partially retarded in their trafficking; they do reach the plasma membrane, albeit to a limited extent, and are partially active. It was subsequently demonstrated that the intrinsic activity of these partially retarded mutants is unaffected by the mutation $[36,37]$. This finding opens the possibility of using pharmacological chaperones that facilitate the routing of trafficking-defective - but otherwise functional- $\mathrm{NCC}$ proteins to the apical membrane for therapeutic use.

Another class of mutations in GS has been recently identified by Riveira-Munoz et al. [38]. This newly identified class includes mutants that are partly retained in the cell. In contrast to the mutants mentioned above, however, these mutants do not show any functional activity and, consequently, pharmacological chaperones will not be of any therapeutic use.

In general, there is extreme inter- and intrafamiliar phenotype variability in GS, the latter emphasizing the lack of a correlation between the severity of symptoms in GS and the type of mutation in the SLC12A3 gene [30]. Recently, however, Riviera-Munoz et al. described a small subgroup of patients with a remarkable severe phenotype, including an early onset, severe neuromuscular manifestations, growth retardation, and ventricular arrhythmias [22]. The majority of these patients was male and carried at least one splice-site mutation, resulting in a truncating transcript, or a non-functional intracellularly retained mutation. Based on their data, these researchers suggested that the nature/position of the SLC12A3 mutation combined with male gender may be a determinant factor in the severity of GS. Studies in lager cohorts are necessary to confirm this proposal.

A minority of patients with the Gitelman phenotype has been shown to have mutations in the $C L C N K B$ gene, which encodes the renal chloride channel $\mathrm{ClC}-\mathrm{Kb}$, located in basolateral membrane of cells of the TAL of Henle's loop and the distal tubules. Mutations in the CLCNKB gene were originally found to be the cause of classic Bartter syndrome $[39,40]$. It is now evident that the clinical phenotype in patients with $C L C N K B$ mutations can be highly variable, varying from an antenatal onset of Bartter syndrome on one side of the spectrum to a phenotype closely resembling GS on the other side (review in [33]). Therefore, there is a medical indication to screen the CLCNKB gene in patients with the Gitelman phenotype who do not have mutations in the SLC12A3 gene.

Both loss-of-function mutations in NCC and mutations in CLC-Kb lead to disruption of $\mathrm{NaCl}$ reabsorption in the DCT (Fig. 2). When less $\mathrm{NaCl}$ is reabsorbed, more sodium will arrive in the collecting duct, resulting in mild volume contraction. The reduced vascular volume activates the renin-angiotensin system, increasing renin activity and aldosterone levels. The elevated aldosterone levels give rise to increased electrogenic sodium reabsorption in the cortical collecting duct via the $\mathrm{ENaC}$, defending salt homeostasis at the expense of increased secretion of potassium and hydrogen ions, thus resulting in hypokalemia and metabolic alkalosis.

Passive $\mathrm{Ca}^{2+}$ reabsorption in the proximal tubule and reduced abundance of the epithelial $\mathrm{Mg}^{2+}$ channel TRPM6, 


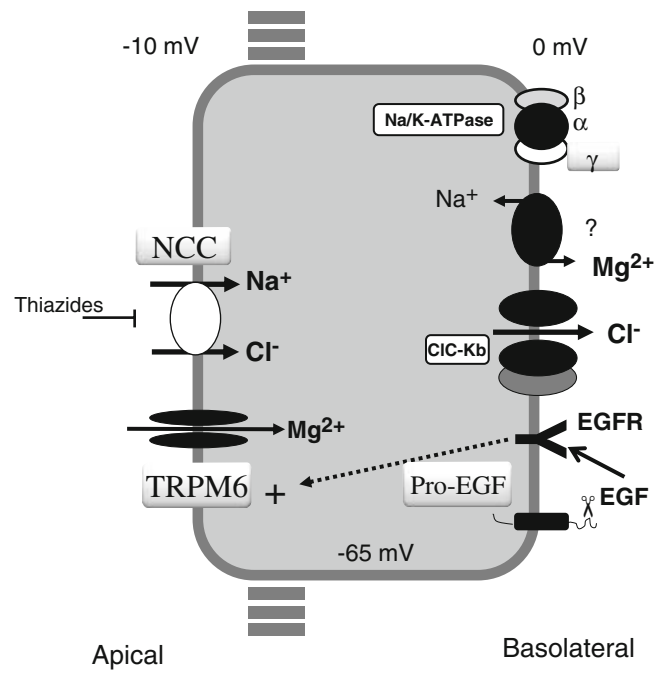

Fig. 2 Speculative cellular model of magnesium transport in the distal convoluted tubule. Magnesium is reabsorbed by the apical transient receptor potential channel melastatin 6 (TRPMO) channel. Indicated also is a putative $\mathrm{Na} / \mathrm{Mg}$ exchanger in the basolateral membrane, which may be responsible for extrusion of $\mathrm{Mg}^{2+}$. The $\mathrm{Na}^{+} / \mathrm{K}^{+}$-ATPase complex, including the $\gamma$-subunit, controls this transcellular $\mathrm{Mg}^{2+}$ transport. Proepithelial growth factor (Pro-EGF) expressed on the basolateral membrane is cleaved to yield EGF, engaging the EGF receptor (EGFR) which in turn stimulates TRPM6 activity. Also indicated are the apical thiazidesensitive $\mathrm{NaCl}$ cotransporter (NCC), through which sodium chloride enters the cell, and the basolateral $\mathrm{Cl}^{-}$channel $(C l C-\mathrm{Kb})$ and $\mathrm{Na}^{+} / \mathrm{K}^{+}$ATPase that are responsible for extrusion of these ions. Both the NCC and $\mathrm{CLC}-\mathrm{Kb}$ are involved in GS

which is located in the DCT, has been shown to explain thiazide-induced hypocalciuria and hypomagnesemia, respectively [41]. Since thiazides are known to inhibit $\mathrm{NCC}$, and in view of the phenotypic resemblance between GS and chronic thiazide-treatment, it is very likely that similar mechanisms are involved in the pathogenesis of the hypocalciuria and hypomagnesemia, respectively, seen in GS patients.

\section{Autosomal dominant renal hypomagnesemia with hypocalciuria}

Autosomal dominant renal magnesium wasting (HOMG2; OMIM 154020), is characterized by hypomagnesemia due to renal magnesium loss and is associated with hypocalciuria [42]. Patients may suffer from generalized convulsions, but they may also be asymptomatic, except for the development of chondrocalcinosis at an adult age. The genetic defect identified in a large Dutch family with this disorder appeared to be a heterozygous missense mutation (G41R) in the FXYD2 gene, which encodes the $\gamma$-subunit of the basolateral $\mathrm{Na}^{+} / \mathrm{K}^{+}$-ATPase which, in turn, is expressed in the basolateral membrane of epithelial cells of the DCT [43]. This $\gamma$-subunit has an important role in modulating the activity of the $\mathrm{Na}^{+} / \mathrm{K}^{+}$-ATPase, which maintains the membrane potential and the $\mathrm{Na}^{+}$gradient [44]. Expression studies in different cell lines have revealed that the mutation in the $\gamma$-subunit abolishes its interaction with the $\alpha \beta$ subunits of the $\mathrm{Na}^{+} / \mathrm{K}^{+}$-ATPase, resulting in a failure of $\gamma$ to traffic to the cell surface and to modulate pump kinetics $[43,45]$. The measurement of serum $\mathrm{Mg}^{2+}$ concentration in two individuals with a heterozygous 11q23-ter deletion (including the FXYD2 gene) revealed that both individuals had normal serum $\mathrm{Mg}^{2+}$ values, indicating that the loss of one FXYD2 gene copy is not sufficient to cause a $\mathrm{Mg}^{2+}$-deficient phenotype [43]. These findings strongly suggest that the hypomagnesemia in the patients with $F X Y D 2$ mutations is caused by a dominant negative effect rather than by haploinsufficiency. The recent finding that $F x y d 2$ knockout mice have normal serum $\mathrm{Mg}^{2+}$ levels and do not show any abnormalities in $\mathrm{Mg}^{2+}$ excretion is consistent with this assumption [46].

The exact molecular mechanism of hypomagnesemia and the associated hypocalciuria in patients with FXYD2 mutations remains to be elucidated. It has been speculated that abrogation of $\gamma$-mediated modulation of the Na-K-ATPase kinetics changes the electrochemical gradients of $\mathrm{Na}^{+}$and $\mathrm{K}^{+}$, with a secondary reduction in $\mathrm{Mg}^{2+}$ reabsorption through the apical TRPM6 channel [47].

Kantorovich et al. recently described another family with autosomal dominant isolated hypomagnesemia, in which they excluded linkage to the chromosomal region of $11 \mathrm{q} 23$ containing the FXYD2 gene [48]. Thus, there is clear evidence for locus heterogeneity for this phenotype.

\section{Familial hypomagnesemia with secondary hypocalcemia}

Familial hypomagnesemia with secondary hypocalcemia (HSH) is a rare autosomal recessive disorder that manifests in the newborn period and is characterized by very low serum $\mathrm{Mg}^{2+}(0.2 \mathrm{mmol} / \mathrm{L})$ [49]. Hypocalcemia is another characteristic feature of this disorder and is a secondary consequence of parathyroid failure and parathyroid hormone (PTH) resistance as a result of chronic, severe hypomagnesemia [50]. The disease typically manifests during the first months of life with generalized convulsions or signs of increased neuromuscular excitability, such as muscle spasms or tetany [51]. Untreated, the disease may be fatal or may lead to severe neurological damage [51, 52]. The immediate administration of magnesium, usually via the intravenous route, followed by lifelong-treatment with high-dose oral magnesium assures the relief of clinical symptoms and normalization of calcium metabolism [52]. In contrast, serum magnesium levels usually fail to reach normal values under oral substitution therapies and remain in the subnormal range $(0.5-0.6 \mathrm{mmol} / \mathrm{L})$. 
Familial HSH is caused by mutations in the TRPM6 gene, which encodes the TRPM6 protein [51, 53, 54]. This protein belongs to the melastatin-related group of a large family of transient receptor potential (TRP) cation channels that play an important role in a wide variety of physiological processes, ranging from thermal, tactile, taste, osmolar, and fluid flow sensing to transepithelial $\mathrm{Ca}^{2+}$ and $\mathrm{Mg}^{2+}$ transport [55]. Detailed electrophysiological analyses and expression studies have demonstrated that TRPM6 confines a $\mathrm{Mg}^{2+}$-permeable channel, which is specifically localized to the apical membrane of $\mathrm{Mg}^{2+}$ - reabsorbing tubules in the kidney (DCT) and the brush-border membrane of the $\mathrm{Mg}^{2+}$ absorptive cells in the small intestine [1] (Fig. 2). By far the majority of mutations found in $\mathrm{HSH}$ patients introduce stop codons, deletions of exons, and frameshifts or affect splice sites, thus resulting in a complete loss-of-function of TRPM6 protein [51]. These inactivation mutations cause the combination of impaired gut reabsorption of $\mathrm{Mg}^{2+}$ and renal wasting seen in $\mathrm{HSH}$.

\section{Isolated autosomal recessive hypomagnesemia (IRH)}

The disease gene in a very rare form of primary hypomagnesemia, called isolated autosomal recessive renal hypomagnesemia (IRH; OMIM 611718), has very recently been identified. This disease was identified 20 years ago in two Dutch sisters from consanguineous parents, who showed psychomotor retardation and epileptic seizures during childhood and who as adults were moderately mentally retarded [56]. Both affected sisters had very low serum $\mathrm{Mg}^{2+}$ levels, while their urinary $\mathrm{Mg}^{2+}$ excretion was in the normal range, pointing to a disturbance in the tubular reabsorption of $\mathrm{Mg}^{2+}$. Apart from hypomagnesemia, no other abnormalities were identified and, in particular, there was no disturbance in urinary calcium excretion. Using a whole genome homozygosity-based mapping strategy followed by fine-mapping, Groenestege et al. identified a critical linkage region of $25.7 \mathrm{cM}$ on chromosome 4 . Within this region, the $E G F$ gene encoding the pro-epidermal growth factor (pro-EGF) was proven to be the disease gene, based on the identification of a homozygous mutation, C3209T in exon 22 in both affected sisters. This mutation caused the substitution of the highly conserved proline 1070 within the cytoplasmic tail of proEGF by leucine (P1070L). Both of parents of the patient, as well as the unaffected sisters were heterozygous for the mutation [57].

Pro-epidermal growth factor is a type-one membrane protein that is expressed at high level in the luminal and at a low level at the basolateral membranes of the DCT [58-60]. It is cleaved by extracellular proteases to generate the active EGF in luminal and basolateral spaces. In a kidney cell line, Groenstege et al. demonstrated that EGF binding to its receptor (EGFR) is essential for the function of TRPM6, which controls magnesium reabsorption in the kidney [57]. As a result of the IRH-associated P1070L mutation, proEGF targeting to the basolateral membrane is disrupted, thereby leading to reduced EGF production in the basolateral space and, consequently, inadequate stimulation of the EGFR on the basolateral membrane. As a result, TRPM6 is insufficiently activated, causing magnesium loss. This model is compatible with the hypomagnesemia previously observed in colon cancer patients treated with the anti-EGF receptor antibody cetuximab [2]. In support of this mechanism, it has been shown that cetuximab also antagonizes the stimulation of TRPM6 activity by EGF in cultured cells [57].

\section{Conclusion}

The etiology and pathophysiology of a significant number of inherited disorders associated with disturbances of renal magnesium transport has been elucidated in recent years. With the knowledge that has been gained, our insight into the physiology of renal magnesium handling has increased significantly. Nevertheless, the molecular mechanisms responsible for the basolateral extrusion of magnesium in the distal convoluted tubule are still completely unknown. Future identification of gene defects in other forms of renal magnesium loss, proven not to be caused by the known disease genes, will be of great help in finding these pieces in the magnesium-transport puzzle.

Open Access This article is distributed under the terms of the Creative Commons Attribution Noncommercial License which permits any noncommercial use, distribution, and reproduction in any medium, provided the original author(s) and source are credited.

\section{References}

1. Voets T, Nilius B, Hoefs S, van der Kemp AW, Droogmans G, Bindels RJ, Hoenderop JG (2004) TRPM6 forms the $\mathrm{Mg}^{2+}$ influx channel involved in intestinal and renal $\mathrm{Mg}^{2+}$ absorption. J Biol Chem 279:19-25

2. Tejpar S, Piessevaux H, Claes K, Piront P, Hoenderop JG, Verslype C, Van Cutsem E (2007) Magnesium wasting associated with epidermal-growth-factor receptor-targeting antibodies in colorectal cancer: a prospective study. Lancet Oncol 8:387-394

3. Praga M, Vara J, González-Parra E, Andrés A, Alamo C, Araque A, Ortiz A, Rodicio JL (1995) Familial hypomagnesemia with hypercalciuria and nephrocalcinosis. Kidney Int 47:1419-1425

4. Manz F, Scharer K, Janka P, Lombeck J (1978) Renal magnesium wasting, incomplete tubular acidosis, hypercalciuria, and nephrocalcinosis in siblings. Eur J Pediatr 128:67-79

5. Evans RA, Carter JN, George CR, Walls RS, Newland RC, McDonnell GD, Lawrence JR (1981) The congenital "magnesium-loosing kidney". Report of two patients. QJM 50:39-52 
6. Benigno V, Canonica CS, Bettinelli A, von Vigier RO (2000) Hypomagnesemia-hypercalciuria-nephrocalcinosis: a report of nine cases and a review. Nephrol Dial Transplant 15:605-610

7. Michelis MF, Drash AL, Linarelli LG, De Rubertis FR, Davis BB (1972) Decreased bicarnonate threshold and renal magnesium wasting in a sibship with distal renal tubular acidosis: evaluation of the pathophysiological role of parathyroid hormone. Metabolism 21:905-920

8. Rodriguez-Soriano J, Vallo A (1994) Pathophysiology of the renal acidification defect present in the syndrome of familial hypomagnesemia-hypercalciuria. Pediatr Nephrol 8:431-435

9. Ulmann A, Hadj S, Lacour B, Bourdeau A, Bader C (1985) Renal magnesium and phosphate wastage in a patient with hypercalciuria and nephrocalcinosis: effect of oral phosphorus and magnesium supplements. Nephron 40:83-87

10. Rodriguez-Soriano J, Vallo A, Garcai-Fuentes M (1987) Hypomagnesemia of hereditary renal origin. Pediatr Nephrol 1:465-471

11. Weber S, Schneider L, Peters M, Misselwitz J, Rönnefarth G, Böswald M, Bonzel KE, Seeman T, Suláková T, Kuwertz-Bröking E, Gregoric A, Palcoux JB, Tasic V, Manz F, Schärer K, Seyberth HW, Konrad M (2001) Novel paracellin-1 mutations in 25 families with familial hypomagnesemia with hypercalciuria and nephrocalcinosis. J Am Soc Nephrol 12:1872-1881

12. Kang JH, Choi HJ, Cho HY, Lee JH, Sa IS, Cheig HI, Choi Y (2005) Familial hypomagnesemia with hypercalciuria and nephrocalcinosis associated with CLDN16 mutations. Pediatr Nephrol 20:1490-1493

13. Simon DB, Lu Y, Choate KA, Velazquez H, Al-Sabban E, Praga M, Casari G, Bettinelli A, Colussi G, Rodriguez-Soriano J, McCredie D, Milford D, Sanjad S, Lifton RP (1999) Paracellin-1 a renal tight junction protein required for paracellular $\mathrm{Mg}^{2+}$ resorption. Science 285:103-106

14. Konrad M, Hou J, Weber S, Dötsch J, Kari JA, Seeman T, Kuwertz-Bröking E, Peco-Antic A, Tasic V, Dittrich K, Alshaya HO, von Vigier RO, Gallati S, Goodenough DA, Schaller A (2008) CLDN16 genotype predicts renal decline in familial hypomagnesemia with hypercalciuria and nephrocalcinosis. J Am Soc Nephrol 19:171-181

15. Morita K, Furuse M, Fukimoto K, Tsukita S (1999) Claudin multigene family encoding four-transmembrane domain protein components of tight junction strands. Proc Natl Acad Sci USA 96:511-516

16. Muller D, Kausalya J, Claverie-Martin F, Meij IC, Eggert P, Garcia-Nieto V, Hunziker W (2003) A novel claudin 16 mutation associated with childhood hypercalciuria abolished binding to ZO1 and results in lysosomal mistargeting. Am J Hum Genet 73:1293-1301

17. Konrad M, Schaller A, Seelow D, Pandey AV, Waldegger S, Lesslauer A, Vitzthum H, Suzuki Y, Luk JM, Becker C, Schlingmann KP, Schmid M, Rodriguez-Soriano J, Ariceta G, Cano F, Enriquez R, Juppner H, Bakkaloglu SA, Hediger MA, Gallati S, Neuhauss SC, Nurnberg P, Weber S (2006) Mutations in the tight junction gene claudin 19 (CLDN19) are associated with renal magnesium wasting, renal failure, and severe ocular involvement. Am J Hum Genet 79:949-957

18. Hou J, Paul DL, Goodenough DA (2005) Paracellin-1 and the modulation of ion selectivity of tight junctions. J Cell Sci 118:5109-5118

19. Hou J, Shan Q, Wang T, Gomes AS, Yan Q, Paul DL, Bleigh M, Goodenough DA (2007) Transgenic RNAi depletion of claudin16 and the renal handling of magnesium. J Biol Chem 282:1711417122

20. Gitelman HJ, Graham JB, Welt LG (1966) A familial disorder characterized by hypokalemia and hypomagnesemia. Trans Assoc Am Physicians 79:221-235
21. Melander O, Ohro-Melander M, Bengtsson K, Lindblad U, Rastam L, Groop L, Hulthen UL (2000) Genetic variants of thiazide-senstive $\mathrm{NaCl}$ cotransporter in Gitelman's syndrome and primary hypertension. Hypertension 36:389-394

22. Riveira-Munoz E, Chang Q, Godefroid N, Hoenderop JG, Bindels RJ, Dahan K, Devuyst O (2007) Belgian Network for Study of Gitelman Syndrome. Transcriptional and functional analyses of SLC12A3 mutations: new clues for the pathogenesis of Gitelman syndrome. J Am Soc Nephrol 1:1271-1283

23. Calò L, Punzi L, Semplicini A (2000) Hypomagnesemia and chondrocalcinosis in Bartter's and Gitelman's syndrome: review of the pathogenetic mechanisms. Am J Nephrol 20:347-350

24. Cruz DN, Shaer AJ, Bia MJ, Lifton RP, Simon DB (2001) Gitelman's syndrome revisited: an evaluation of symptoms and health-related quality of life. Kidney Int 59:710-717

25. Foglia PEG, Bettineli A, Tosetto C, Cortesi C, Crosazzo L, Edefonti A, Bianchetti MG (2004) Cardiac work up in primary hypokalemia-hypomagnesemia (Gitelman syndrome). Nephrol Dial Transplant 19:1398-1402

26. Scognamiglio R, Negut C, Calò LA (2007) Aborted sudden cardiac death in two patients with Bartter's/Gitelman's syndromes. Clin Nephrol 67:193-197

27. Fava C, Montagnana M, Rosberg L, Burri P, Almgren P, Jönsson A, Wanby P, Lippi G, Minuz P, Hulthèn LU, Aurell M, Melander O (2008) Subjects heterozygous for genetic loss of function of the thiazide-sensitive cotransporter have reduced blood pressure. Hum Mol Genet 17:413-418

28. Ji W, Foo JN, O'Roak BJ, Zhao H, Larson MG, Simon DB, Newton-Cheh C, State MW, Levy D, Lifton RP (2008) Rare independent mutations in renal salt handling genes contribute to blood pressure variation. Nat Genet 40:592-599

29. Cruz DN, Simon DB, Nelson-Williams C, Farhi A, Finberg K, Burleson L, Gill JR, Lifton RP (2001) Mutations in the Na-Cl cotransporter reduce blood pressure in humans. Hypertension 37:1458-1464

30. Lin SH, Cheng NL, Hsu YJ, Halperin ML (2004) Intrafamiliar phenotype variability in patients with Gitelman syndrome having the same mutations in their thiazide-sensitive sodium/chloride cotransporter. Am J Kidney Dis 43:304-312

31. Firoz M, Braber M (2001) Bioavailability of U.S. commercial magnesium preparations. Magnesium Res 4:257-262

32. Bonfante L, Davis PA, Spinello M, Antonello A, D'Angelo A, Semplicini A, Galo L (2001) Chronic renal failure, end-stage renal disease, and peritoneal dialysis in Gitelman's syndrome. Am J Kidney Dis 38:165-168

33. Knoers NVAM, Starremans PGJF, Monnens LAH (2005) Hypokalemic tubular disorders. In Davidson AM, Cameron JS, Grunfeld J-P, Ponticelli C, Ritz E, Winearls CG, van Ypersele C (eds) Oxford textbook in clinical nephrology, 3rd edn. Oxford University Press, Oxford, pp 995-1004

34. Gamba G, Saltzberg SN, Lombardi M, Miyanoshita A, Lytton J, Hediger MA, Brenner BM, Hebert SC (1993) Primary structure and functional expression of a cDNA encoding the thiazidesensitive, electroneutral sodium-chloride cotransporter. Proc Natl Acad Sci USA 90:2749-2753

35. de Jong JC, van der Vliet WA, van den Heuvel LPWJ, Willems PHGM, Knoers NVAM, Bindels RJM (2002) Functional expression of mutations in the human $\mathrm{NaCl}$ cotransporter (NCC): evidence for impaired routing mechanisms in Gitelman's syndrome. J Am Soc Nephrol 13:1442-1448

36. de Jong JC, Willems PHGM, Mooren FJM, van den Heuvel PWJ, Knoers NVAM, Bindels RJM (2003) The structural unit of the thiazide-sensitive $\mathrm{NaCl}$ cotransporter $(\mathrm{NCC})$ is a homodimer. $\mathrm{J}$ Biol Chem 278:24302-24307 
37. Sabath E, Meade P, Berkman J, de los Heros P, Moreno E, Bobadilla NA, Vazquez N, Ellison DH, Gamba G (2004) Pathophysiology of functional mutations of the thiazide-sensitive $\mathrm{Na}-\mathrm{Cl}$ cotransporter in Gitelman disease. Am J Physiol Renal Physiol 287:F195-F203

38. Riveira-Munoz E, Chang Q, Bindels RJ, Devuyst O (2007) Gitelman's syndrome: towards genotype-phenotype correlations? Pediatr Nephrol 22:326-332

39. Simon DB, Bindra RS, Mansfield TA, Nelson-Williams C, Mendonca E, Stone R, Schurman S, Nayir A, Alpay H, Bakkaloglu A, Rodriguez-Soriano J, Morales JM, Sanjad SA, Taylor CM, Pilz D, Brem A, Trachtman H, Griswold W, Richard GA, John E, Lifton RP (1997) Mutations in the chloride channel gene, CLCNKB, cause Bartter's syndrome type III. Nat Genet 17:171-178

40. Konrad M, Vollmer M, Lemmink HH, van den Heuvel LP, Jeck N, Vargas-Poussou R, Lakings A, Ruf R, Deschênes G, Antignac C, Guay-Woodford L, Knoers NV, Seyberth HW, Feldmann D, Hildebrandt F (2000) Mutations in the chloride channel gene CLCNKB as a cause of classic Bartter syndrome. J Am Soc Nephrol 11:1449-1459

41. Nijenhuis T, Vallon V, van der Kemp AWCM, Loffing J, Hoenderop JG, Bindels RJ (2005) Enhanced passive $\mathrm{Ca}^{2+}$ reabsorption and reduced $\mathrm{Mg}^{2+}$ channel abundance explains thiazide-induced hypocalciuria and hypomagnesemia. J Clin Invest 115:1651-1658

42. Geven WB, Monnens LA, Willems HL, Buijs WC, ter Haar BG (1987) Renal magnesium wasting in two families with autosomal dominant inheritance. Kidney Int 31:1140-1144

43. Meij IC, Koenderink JB, van Bokhoven H, Assink KFH, Tiel Groenestege W, de Pont JJHHM, Bindels RJM, Monnens LAH, van den Heuvel LPWJ, Knoers NVAM (2000) Dominant isolated renal magnesium loss is caused by misrouting of the $\mathrm{Na}(+), \mathrm{K}(+)-$ ATPase gamma subunit. Nat Genet 26:265-266

44. Arystarkhova E, Wetzel RK, Asinovski NK, Sweadner KJ (1999) The $\gamma$ subunit modulates $\mathrm{Na}^{+}$and $\mathrm{K}^{+}$affinity of the renal Na,K-ATPase. J Biol Chem 274:33183-33185

45. Meij IC, Koenderink JB, De Jong JC, De Pont JJ, Monnens LA, Van Den Heuvel LP, Knoers NV (2003) Dominant isolated renal magnesium loss is caused by misrouting of the $\mathrm{Na}, \mathrm{K}$, ATPase gamma subunit. Ann NY Acad Sci 986:437-443

46. Jones DH, Li TY, Arysarkhova E, Barr KJ, Wetzel RK, Peng J, Markham K, Sweadner KJ, Fong G-H, Kidder GM (2005) Na,K, ATPase from mice lacking the $\gamma$-subunit (fxyd2) exhibits altered $\mathrm{Na}^{+}$ affinity and decreased thermal stability. J Biol Chem 280:1900319011

47. Hoenderop JGJ, Bindels RJM (2005) Epithelial $\mathrm{Ca}^{2+}$ and $\mathrm{Mg}^{2+}$ channels in health and disease. J Am Soc Nephrol 16:15-26

48. Kantorovich V, Adams JS, Gaines JE, Guo X, Pandian M, Cohn D, Rude R (2002) Genetic heterogeneity in familial renal magnesium wasting. J Endocrinol Metab 87:612-617
49. Paunier L, Radde IC, Kooh SW, Conen PE, Fraser D (1968) Primary hypomagnesemia with secondary hypocalcemia in an infant. Pediatrics 41:385-402

50. Anast CS, Mohs JM, Kaplan SL, Bruns TW (1972) Evidence for parathyroid failure in magnesium deficiency. Science 177:606608

51. Schlingmann KP, Sassen MC, Weber S, Pechmann U, Kusch K, Pelken L, Lotan D, Syrrou M, Prebble JJ, Cole DEC, Metger DL, Rahman S, Tajima T, Shu S-G, Waldegger S, Seyberth HW, Konrad M (2005) Novel TRPM6 mutations in 21 families with primary hypomagnesemia and secondary hypocalcemia. J Am Soc Nephrol 16:3061-3069

52. Shalev H, Phillip M, Galil A, Carmi R, Landau D (1998) Clinical presentation and outcome in primary familial hypomagnesemia. Arch Dis Child 78:127-130

53. Schlingmann KP, Weber S, Peters M, Niemann Nejsum L, Vitzthum H, Klingel K, Kratz M, Haddad E, Ristoff E, Dinour D, Syrrou M, Nielsen S, Sassen M, Waldegger S, Seyberth HW, Konrad M (2002) Hypomagnesemia with secondary hypocalcemia is caused by mutations in TRPM6, a new member of the TRPM gene family. Nat Genet 31:166-170

54. Walder RY, Landau D, Meyer P, Shalev H, Tsolia M, Borochowitz Z, Boettger MB, Beck GE, Englehardt RK, Carmi R, Sheffield VC (2002) Mutation of the TRPM6 causes familial hypomagnesemia with secondary hypocalcemia. Nat Genet 31:171-174

55. Clapham DE (2003) TRP channels as cellular sensors. Nature 426:517-524

56. Geven WB, Monnens LA, Willems JL, Buijs W, Hamel BCJ (1987) Isolated autosomal recessive renal magnesium loss in two sisters. Clin Genet 32:398-402

57. Groenestege WM, Thebault $\mathrm{S}$, van der Wijst J, van den Berg D, Janssen R, Tejpar S, van den Heuvel LP, van Cutsem E, Hoenderop JG, Knoers NV, Bindels RJ (2007) Impaired basolateral sorting of the pro-EGF causes isolated renal hypomagnesemia. J Clin Invest 117:2260-2267

58. Bell GI, Fong NM, Stempien MM, Wormsted MA, Caput D, Ku LL, Urdea MS, Rall LB, Sanchez-Pescador R (1986) Human epidermal growth factor precursor: cDNA sequence, expression in vitro and gene organization. Nucleic Acids Res 14:84278446

59. Loffing J, Loffing-Cueni D, Valderrabano V, Kläusli L, Hebert SC, Rossier BC, Hoenderop JG, Bindels RJ, Kaissling B (2001) Distribution of transcellular calcium and sodium transport pathways along mouse distal nephron. Am J Physiol Renal Physiol 281: F1021-F1027

60. Dempsey PJ, Meisse KS, Yoshitake Y, Nishikawa K, Coffey RJ (1997) Apical enrichment of human EGF precursor on MadinDarby canine kidney cells involves preferential basolateral ectodomain cleavage sensitive to metalloprotease inhibitor. J Cell Biol 138:747-758 